\title{
Aerosol Loading and Its Implications on Atmospheric Corrosion over Tokoradi
}

\author{
Emetere E. Moses ${ }^{1,3^{*}}$, Emetere J. Makuachukwu ${ }^{2}$, Falade Adesola ${ }^{4}$, Odun-Ayo Isaac ${ }^{4}$ \\ ${ }^{1}$ Department of Physics, Covenant University Canaan land, P.M.B 1023, Ota, Nigeria \\ ${ }^{2}$ Department of Mathematics, Federal University of Technology, Minna, Nigeria \\ ${ }^{3}$ Department of Mechanical Engineering and Science, University of Johannesburg, APK, South Africa \\ ${ }^{4}$ Department of Computer Science, Covenant University Canaan land, P.M.B 1023, Ota, Nigeria
}

Corresponding Author Email: emetere@yahoo.com

https://doi.org/10.18280/i2m.180214

Received: 11 January 2019

Accepted: 20 March 2019

\section{Keywords:}

aerosol loading, aerosol, atmospheric corrosion, Tokoradi, Ghana, model

\begin{abstract}
Aerosol loading is now a veritable tool for understanding air quality over geographical regions. It also approximately evaluates the cumulative health risk from various pollutants in the atmosphere. In this research, the focus is to see the effect of aerosol loading on atmospheric corrosion. The dataset used for this study was obtained from satellite measurement. Fifteen years primary (aerosol optical depth) dataset was obtained from the Multi-angle Imaging Spectro-Radiometer (MISR). Using mathematical and computational experimentations, the reliability of the dataset was examined and applied in determining the aerosol loading as well as the atmospheric corrosion parameter i.e. corrosion rate. The results show that the atmospheric corrosion over the study area is high and there may be huge loss of uncoated metal surface due to corrosion.
\end{abstract}

\section{INTRODUCTION}

The successes of aerosol loading as a vital tool for determing air quality over a geographical space is undeniably significant. Generally, it gives a cumulative effect of aerosols deposited in the atmosphere for a period of time. The highlights of aerosol loading are its ability to give the aggregate effect of all aerosols per time without necessarily involving the lifetimes of aerosols. This attribute of aerosol loading is significant for short-term research and extensive research work [1-3]. However, the shortcoming of aerosol loading is its inability to determine the effects of individual pollutants in the atmosphere.

The economic loss due to corrosion is huge. In the US, the total annual corrosion costs in the U.S. rose above \$1 trillion in the middle of 2013, illustrating the broad and expensive challenge that corrosion presents to equipment and materials and is now estimated at \$1.1 trillion for 2016 (G2MT, 2019). The indirect costs incurred by corrosion in developing countries are huge and may hit 2 trillion in 2020. For example, regions with high aerosol loading are proposed to aid corrosion rate of roofing sheets used in rural areas of developing and under-developed countries. The corrosion of metallic surfaces (Figure 1) are traced to atmospheric corrosion which entails the deposition of gaseous pollutant in the atmosphere that are predominantly dispersed by biomass burning e.g. coal, oil, agricultural waste, industrial waste, building waste, domestic waste, and gasoline [4].

Aside biomass burning, the West Africa region is highly affected by Sahara dust [1]. Sahara dust contains quartz $(21.26 \%)$, dolomite $(14.58 \%)$, calcite $(14.21 \%)$, smectite $(9.10 \%)$, halite $(7.99 \%)$ and kaolinite $(7.89 \%)$ - [5]. These components are essential agents that aid atmospheric corrosion. Hence, the sources and elemental composition of atmospheric aerosols in West Africa is of huge interest to understand the level of atmospheric corrosion [6]. In this paper, we considered the analysis of aerosol loading and how it is related to atmospheric corrosion.

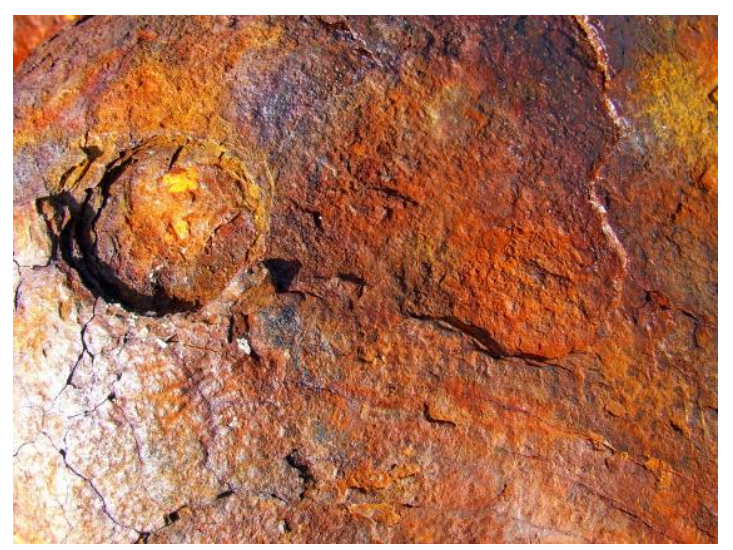

Figure 1. Effect of atmospheric corrosion on metallic surfaces

\section{EXPERIMENTAL DESIGN, MATERIALS AND METHODS}

Tokoradi is located in Ghana. It is an industrial and commercial center, with a population of over 400,000 people. The research site is located on latitude and longitude of $4.9016^{\circ} \mathrm{N}$ and $1.7831^{\circ} \mathrm{W}$ respectively (Figure 2).

The aerosol parameter used for this study is the aerosol optical depth (AOD) that was obtained from the Multi-angle Imaging Spectro-Radiometer (MISR). The raw dataset for fourteen years was treated using the excel programmed. The distribution of the AOD distribution, as well as the statistical and computational analysis was performed to know the 
reliability of the AOD. The West African regional scale dispersion model (WASDM) was used for calculating aerosol loading over the research site:
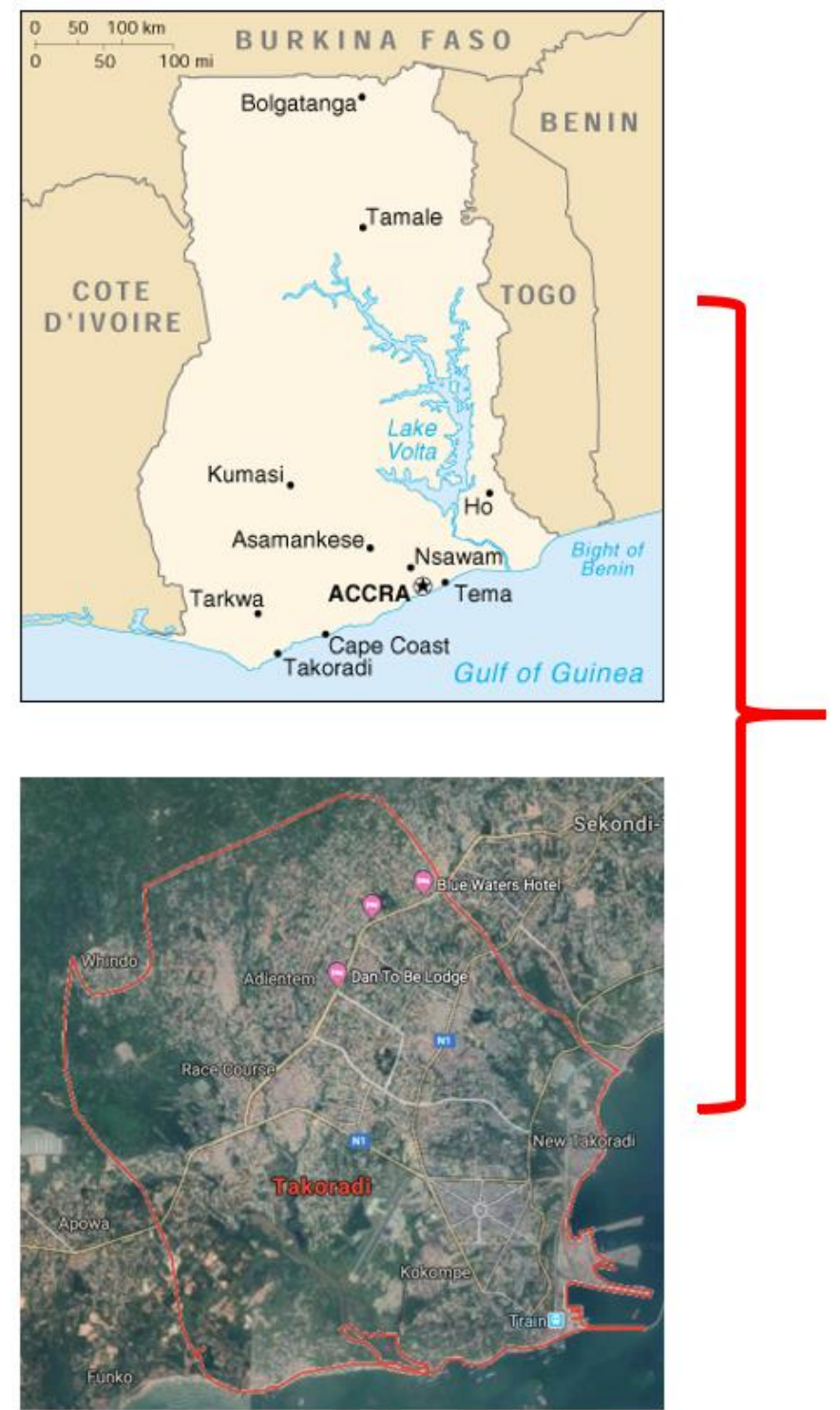

Figure 2. Geographical map of Tokoradi

$$
\begin{array}{r}
\psi(\lambda)=a_{1}{ }^{2} \cos \left(\frac{\mathrm{n}_{1} \pi \tau(\lambda)}{2} x\right) \cos \left(\frac{\mathrm{n}_{1} \pi \tau(\lambda)}{2} y\right)+ \\
\cdots \ldots a_{n}{ }^{2} \cos \left(\frac{\mathrm{n}_{\mathrm{n}} \pi \tau(\lambda)}{2} x\right) \cos \left(\frac{\mathrm{n}_{\mathrm{n}} \pi \tau(\lambda)}{2} y\right)
\end{array}
$$

a is atmospheric constant gotten from the fifteen years aerosol optical depth (AOD) dataset from MISR, $\mathrm{n}$ is the tuning constant, $\tau(\lambda)$ is the AOD of the area and $\psi(\lambda)$ is the aerosol loading. The dataset was processed using the excel. The validation of the summarized dataset was done using mathematical models and statistical softwares. The analysis of equations (1) was done using the $\mathrm{C}++$ codes.

The atmospheric corrossion rate of metals over the Tokoradi was calculated using the Faraday equation [7]. It is given as :

$$
C R\left(\frac{\mu m}{y r}\right)=k \frac{i_{\text {corr }}}{d} E W
$$

where $\mathrm{k}$ is a conversion factor $\left(3.27 \mathrm{x} 106 \mu \mathrm{m} \cdot \mathrm{g} \cdot \mathrm{A}^{-1} \cdot \mathrm{cm}^{-1} \cdot \mathrm{yr}\right.$ ${ }^{1}$ ), icorr is the corrosion current density in $\mu \mathrm{A} / \mathrm{cm}^{2}$ (calculated from the measurements of Rp), EW is the equivalent weight, and $\mathrm{d}$ is the density of Alloy $22\left(8.69 \mathrm{~g} / \mathrm{cm}^{3}\right)$.

Based on equation (2), the modification in the work is the inclusion of aerosol loading.

$$
C R\left(\frac{\mu m}{y r}\right)=k \frac{i_{\text {corr }}}{d} E W / \exp \left(\frac{E W * \varphi(\lambda)}{2.32}\right)
$$

In this study, the corrosion current density of iron was considered and it is given as $3.2 \times 10^{-3} \mu \mathrm{A} / \mathrm{cm}^{2}$. The EW of iron is given as 27.9225 .

The number of pages for the manuscript must be no more than ten, including all the sections. Please make sure that the whole text ends on an even page. Please do not insert page numbers. Please do not use the Headers or the Footers because they are reserved for the technical editing by editors.

\section{RESULTS AND DISCUSSION}

The daily AOD of the four spectral bands for fourteen years were presented in Figure 3. The peaks in the plot represent the maximum for each year. In 2006, the region observed the highest aerosol deposition into the atmosphere. The AOD spatial distribution over the fourteen years can be found in Figure 4 . The contour compression over the geographical area shows the ocean-land wind interaction. Hence, aside the Sahara dust earlier discussed, the presence of sea salt is a huge possibility.

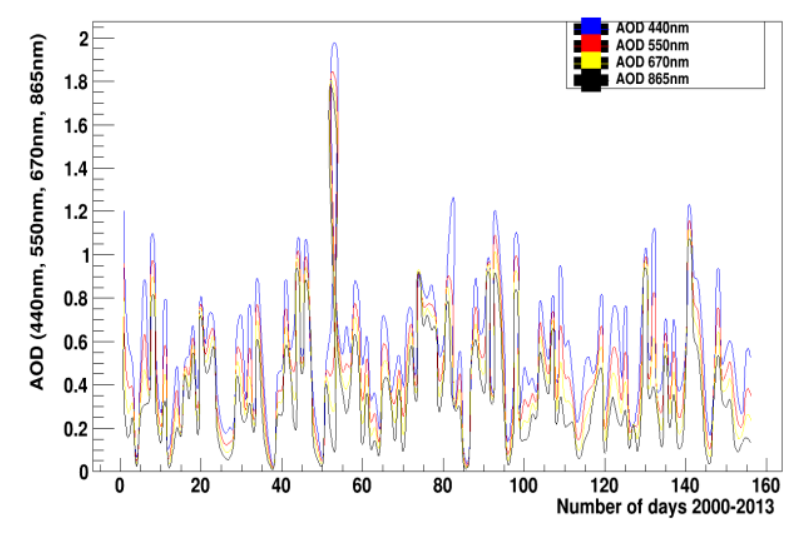

Figure 3. Daily AOD over Tokoradi

Since the aerosols over Tokoradi is projected to be a combination of aersosols from mainly anthropogenic pollution, marine aerosol and Sahara dust, the interaction of the spectra bands representing each pollution source was demonstrated as shown in Figure 5.

It was affirmed that the marine aerosol is significant in the research site (Figure 5b) and corroborates the report of Huang et al. [8]. Sahara dust and biomass burning were also found to be dominant as shown in Figures $5 \mathrm{c} \&$ d. 

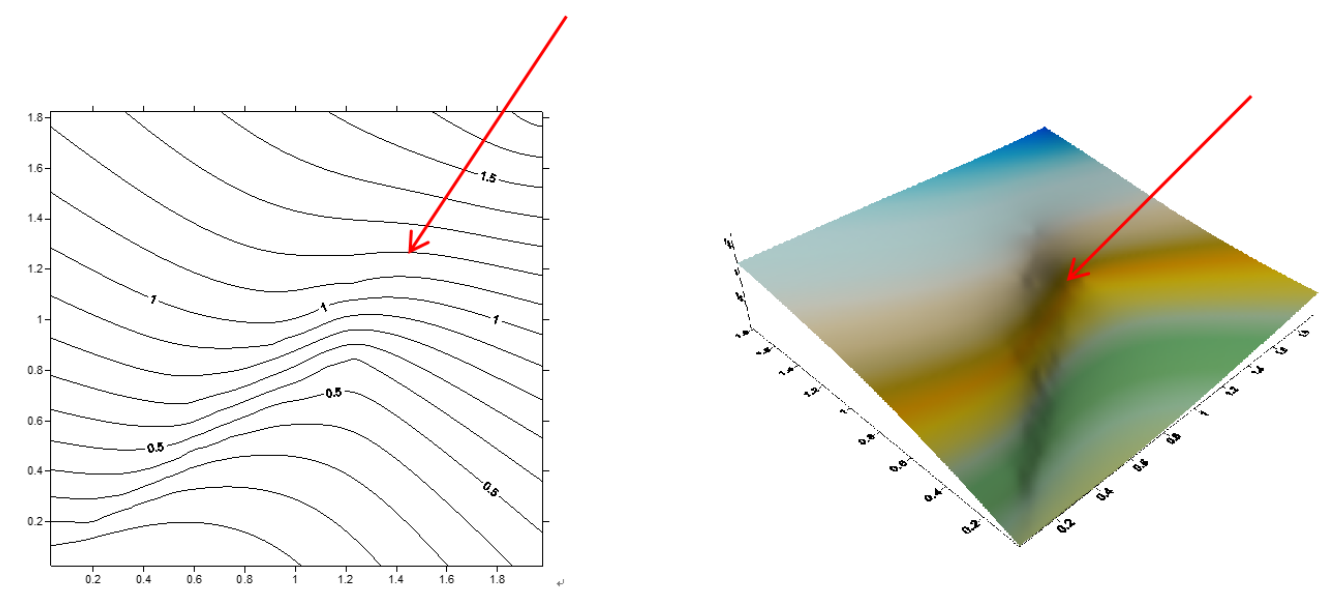

Figure 4. Spatial distribution of AOD over Tokoradi
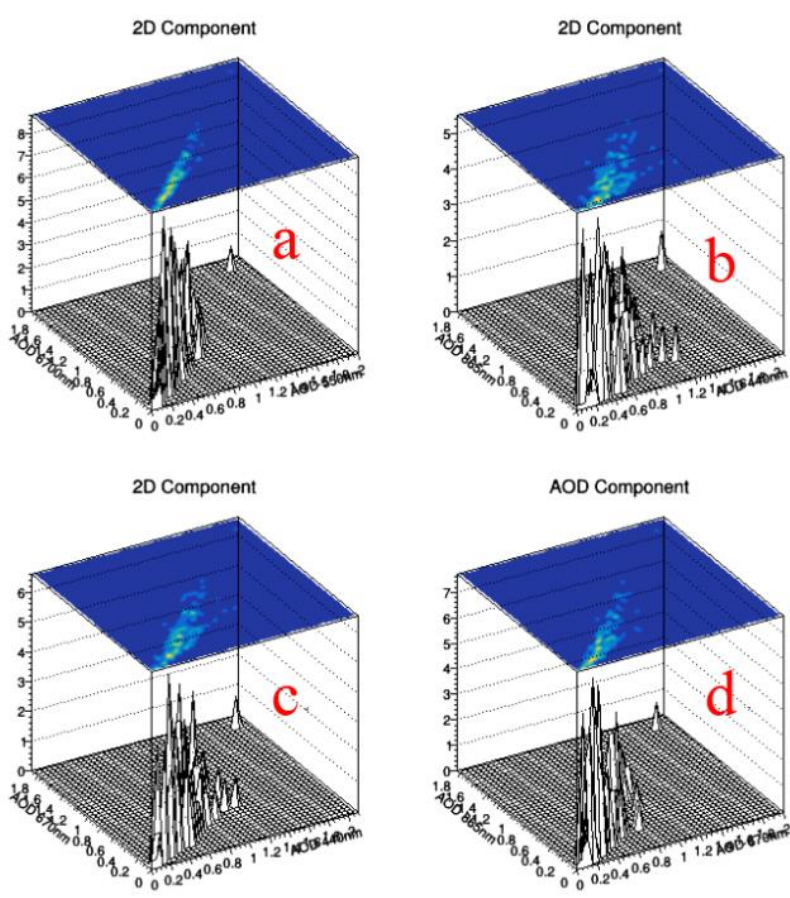

Figure 5. Investigation on dominant atmospheric aerosols in Tokoradi

Table 1. Univariate statistics over Tokoradi

\begin{tabular}{cccc}
\hline & $\mathbf{X}$ & $\mathbf{Y}$ & $\mathbf{Z}$ \\
\hline Minimum: & 0.032 & 0.026 & 0.023 \\
25\%-tile: & 0.37 & 0.286 & 0.221 \\
Median: & 0.535 & 0.448 & 0.38 \\
75\%-tile: & 0.738 & 0.617 & 0.549 \\
Maximum: & 1.979 & 1.825 & 1.747 \\
Midrange: & 1.0055 & 0.9255 & 0.885 \\
Range: & 1.947 & 1.799 & 1.724 \\
Interquartile Range: & 0.368 & 0.331 & 0.328 \\
Median Abs. Deviation: & 0.183 & 0.168 & 0.163 \\
Mean: & & & 0.40858974358974 \\
Trim Mean (10\%): & 0.56744230769231 & 0.47028846153846 & 0.39278873239437 \\
Standard Deviation: & 0.55616197183099 & 0.45757746478873 & 0.26019794909899 \\
Variance: & 0.29053525405893 & 0.071369415068276679 & 0.067702972715319 \\
Coef. of Variation: & 0.084410733851085 & & 0.63681958047446 \\
Coef. of S kewness: & & & 1.3222693137724 \\
\hline
\end{tabular}


Table 2. Inter-variable correlation over Tokoradi

\begin{tabular}{cccc}
\hline & $\mathbf{X}$ & $\mathbf{Y}$ & $\mathbf{Z}$ \\
\hline $\mathrm{X}:$ & 1.000 & 0.978 & 0.933 \\
$\mathrm{Y}:$ & & 1.000 & 0.988 \\
$\mathrm{Z}:$ & & 1.000 \\
\hline
\end{tabular}

Table 3. Inter-variable covariance over Tokoradi

\begin{tabular}{cccc}
\hline & $\mathbf{X}$ & $\mathbf{Y}$ & $\mathbf{Z}$ \\
\hline $\mathrm{X}:$ & 0.084410733851085 & 0.075871718565089 & 0.070544162228797 \\
$\mathrm{Y:}$ & & 0.071369487302761 & 0.068669906804734 \\
$\mathrm{Z:}$ & & & 0.067702972715319 \\
\hline
\end{tabular}

Table 4. Planar regression: $\mathrm{Z}=\mathrm{AX}+\mathrm{BY}+\mathrm{C}$ over Tokoradi

Fitted Parameters

\begin{tabular}{cccc}
\hline & A & B & C \\
\hline Parameter Value: & -0.65489717123311 & 1.6583849084905 & 0.00028681848281541 \\
Standard Error: & 0.0060488064339348 & 0.0065782782055274 & 0.00085407921612932 \\
\hline
\end{tabular}

Table 5. Inter-Parameter correlations over Tokoradi

\begin{tabular}{lccc}
\hline & A & B & C \\
\hline A: & 1.000 & 0.978 & -0.478 \\
B: & & 1.000 & -0.306 \\
C: & & & 1.000 \\
\hline
\end{tabular}

Table 6. ANOVA table over Tokoradi

\begin{tabular}{ccccc}
\hline Source & df & Sum of Squares & Mean Square & F \\
\hline Regression: & 2 & 10.558386512197 & 5.2791932560984 & $2.4646 \mathrm{E}+005$ \\
Residual: & 153 & 0.0032772313928788 & $2.1419813025352 \mathrm{E}-005$ & \\
Total: & 155 & 10.56166374359 & & \\
\hline Cotficis
\end{tabular}

Coefficient of Multiple Determination $\left(\mathrm{R}^{\wedge} 2\right)$ : 0.99968970500553

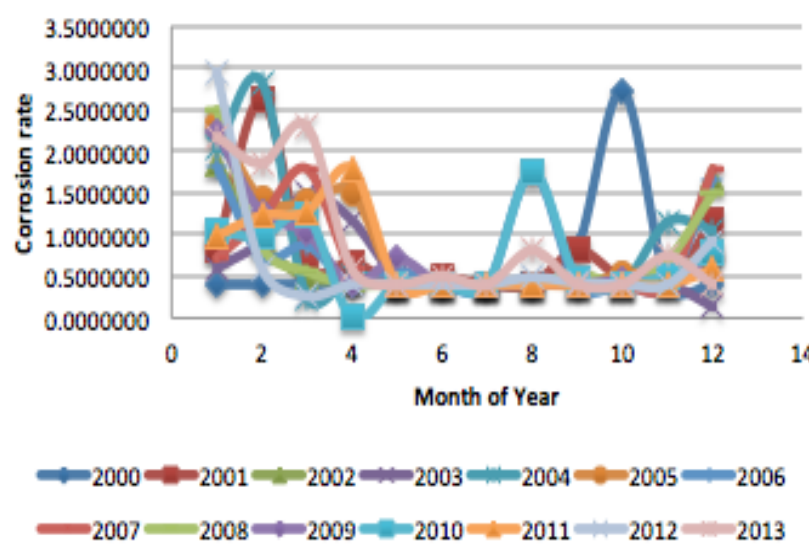

Figure 6. Approximate corrosion rate over Tokoradi

The Sahara dust infiltration into the region corroborates past research work [1,9]. Figure 5a shows that there are low representations of transported aerosols from neighboring cities. The statistical approach (Tables 1-6) was done to affirm the results presented in Figure 5. The summation of the univariate statistics, inter-variable correlation, inter-variable covariance, planar regression, inter-parameter correlations and ANOVA show that the AOD of Tokoradi is high and may exceed the limits described by World Health Organization [10].

The corrosion rate as calculated from equation (3) is presented in Figure 6. It is observed that the maximum corrosion rate is observed between December and April of every year.
Since the average annual temperature and rainfall over Tokoradi is $25.9{ }^{\circ} \mathrm{C}$ and $1343 \mathrm{~mm}$ respectively. At this temperature, many scientists [11-14] believe that corrosion would be highly aided. Hence, coupled with the salts traced to its atmospheric aerosols, there awaits huge economic loss due to corrosion of metallic surfaces in Tokoradi.

\section{CONCLUSION}

It was observed that the ocean-land wind system over Tokoradi aided the marine aerosols and sea salts that was reported to aid the corrosion rates of metallic surfaces. Also, the Sahara dust influx has great contribution towards the atmospheric corrosion of the geographical area. The corrosion rate over Tokoradi is found to be maximum between December and April. Hence, it is affirmed that atmospheric corrosion is directly related to aerosol loading. It is recommended that government of Ghana should embark on a comprehensive ground measurement exercise in the research site. This would give strength to the outcome of the research and a valid prove to educate the public on indiscriminate pollution of the atmosphere.

\section{ACKNOWLEDGMENT}

The authors appreciate Covenant University for partial sponsorship. The authors acknowledge NASA for primary dataset. 


\section{REFERENCES}

[1] Emetere, Eterigho, M. (2016). Statistical examination of the aerosols loading over Mubi-Nigeria: The satellite observation analysis. Geographica Panonica, 20(1): 4250. https://doi.org/10.5937/GeoPan1602062E

[2] Emetere, M.E. (2016). Generation of atmospheric constants over some locations in West Africa: A theoretical aid for measuring instruments design. International Journal of Engineering Research in Africa, 27:

$119-146$

https://doi.org/10.4028/www.scientific.net/JERA. 27.119

[3] Emetere, M.E. (2016). Numerical modelling of west africa regional scale aerosol dispersion. Doctoral Thesis. Covenant University, Nigeria. 65-289.

[4] Haywood, J.M., Pelon, J., Formenti, P., Bharmal, N.A., Brooks, M., Capes, G., Chazette, P., Chou, C., Christopher, S., Coe, H., Cuesta, J., Derimian, Y., Desboeufs, K., Greed, G., Harrison, M., Heese, B., Highwood, E.J., Johnson, B.T., Mallet, M., Marticorena, B., Marsham, J., Milton, S., Myhre, G., Osborne, S.R., Parker, D.J., Rajot, J.L., Schulz, M., Slingo, A., Tanre, D., Tulet, P. (2008). Overview of the dust and biomass burning experiment and African monsoon, multidisciplinary analysis special observing period-0. Journal of Geophysical Research, 113: 1-12. https://doi.org/10.1029/2008JD010077

[5] Diaz-Hernandez, J.L, Martín-Ramos, J.D., LópezGalindo, A. (2011). Quantitative analysis of mineral phases in atmospheric dust deposited in the south-eastern Iberian Peninsula. Atmospheric Environment, 45: 30153024. https://doi.org/10.1016/j.atmosenv.2011.03.024

[6] Alastuey, A., Querol, X., Castillo, S., Escudero, M., Ávila, A., Cuevas, E., Torres, C., Romero, P., Expósito, F., García, O., Díaz, J.P., Dingenen, R., Putaud, J.P. (2005). Characterization of TSP and PM2.5 at Izaña and Sta. Cruz de Tenerife (Canary Islands, Spain) during a Saharan dust episode (July 2002). Atmos. Environ, 39: 4715-4728.

[7] ASTM International, Volume 03.02, Standards G 5, G 48, G 59, G 61, G 102 (ASTM International, 2003: West Conshohocken.

[8] Huang, J., Zhang, C., Prospero, J.M. (2009). African aerosol and large-scale precipitation variability over West Africa. Environmental Research Letters, 4(1). Article ID 015006, 2009. https://doi.org/10.1088/17489326/4/1/015006
[9] Ullerstam, M., Johnson, M.S., Vogt, R., Ljungström, E. (2003). DRIFTS and Knudsen cell study of the heterogeneous reactivity of $\mathrm{SO}_{2}$ and $\mathrm{NO}_{2}$ on mineral dust. Atmos. Chem. Phys., 3: 2043-2051. https://doi.org/10.5194/acpd-3-4069-200

[10] WHO. (2018a). Air pollution. http://www.who.int/airpollution/en/ (accessed 5th July, 2018)

[11] Tang, J., Shao, Y., Guo, J., Zhang, T., Meng, G., Wang, F. (2010). The effect of H2S concentration on the corrosion behavior of carbon steel at $90 \mathrm{oC}$. Corrosion Science, 52(6): 2050-2058. https://doi.org/10.1016/j.corsci.2010.02.004

[12] Qi, Y., Luo, H., Zheng, S., Chen, C., Lv, Z., Xiong, M. (2014). Effect of temperature on the corrosion behavior of carbon steel in hydrogen sulphide environments. International Journal of Electrochemical Science, 9: 2101-2112. https://doi.org/10.1063/1.5010557

[13] Sun, W., Nesic, S., Papavinasam, S. (2006). Kinetics of iron sulfide and mixed iron sulfide/carbonate scale precipitation in $\mathrm{CO} 2 / \mathrm{H} 2 \mathrm{~S}$ corrosion, CORROSION/2006, paper no. 06644 (San Diego, CA: NACE, 2006). https://doi.org/10.5006/1.3278494

[14] Ma, H., Cheng, X., Li, G., Chen, S., Quan, Z., Zhao, S., Niu, L. (2000). The influence of hydrogen sulfide on corrosion of iron under different conditions. Corrosion Science, 42(10): 1669-1683.

\section{NOMENCLATURE}

is atmospheric constant gotten from the fifteen years aerosol optical depth (AOD) dataset from MISR,

$\mathrm{n} \quad$ tuning constant

$\mathrm{k} \quad$ conversion factor $\left(3.27 \times 106 \mu \mathrm{m} \cdot \mathrm{g} \cdot \mathrm{A}^{-1} \cdot \mathrm{cm}^{-}\right.$ icorr corrosion current density in $\mu \mathrm{A} / \mathrm{cm}^{2}$ EW (calculated from the measurements of Rp),

EW equivalent weight

d density of Alloy

\section{Greek symbols}

$\begin{array}{ll}\tau(\lambda) & \text { is the AOD of the area } \\ \psi(\lambda) & \text { aerosol loading }\end{array}$ 